\title{
Development of a Priority Scale in Handling National Road Maintenance in Banten
}

\author{
Novel Ridwan \\ Master of Civil Engineering Study Program Student \\ Tarumanagara University \\ Jakarta, Indonesia \\ novel78ridwan.com@gmail.com
}

\author{
Leksmono Suryo Putranto \\ Civil Engineering Department \\ Tarumanagara University \\ Jakarta, Indonesia \\ leksmonop@ft.untar.ac.id
}

\begin{abstract}
National road should be maintained periodically to keep its performance in a serviceable condition. Banten is a province next to the capital of Indonesia, Jakarta. Therefore, road maintenance in this area must be conducted properly. Banten is one of the areas in Indonesia, in which the national road maintenance is conducted based on a long segment system. Long segment system is a road preservation handling within a continuous segment to acquire stable road condition along the segment according to the standard. According to General Specification of Ministry of Public Works and Public Housing (2018), 6 aspects should be maintained in a national road. Altogether there are 20 criteria within those 6 aspects. This paper is intended to develop a priority scale to choose which aspects and criteria should be given more priority if a limited budget is available. Using the analytical hierarchy process (AHP), we found from 30 respondents who deal with national road maintenance daily that drainage was the most important maintenance aspect (weight 0.251 ).
\end{abstract}

Keywords: priority scale, national road, maintenance, $A H P$

\section{INTRODUCTION}

Law No.22 Year 2009 on Traffic and Road Transport [1] Article 24 dictates (1) it is mandatory for the road operator to repair road damage which may cause traffic accidents, and (2) in the situation in which the road repair as mentioned in verse 1 , it is mandatory for the road operator to install appropriate road signs to avoid traffic accidents.

There are four categories of road maintenance, i.e. routine maintenance, periodic maintenance, rehabilitation, and betterment. Routine maintenance is the activities of repairing stable road links. This is applied only in the surface layer to improve riding quality without improving structural strength and conducted daily over a year. Periodical maintenance is a road handling toward every damage which is considered in the design to restore the planned stable condition. Periodical maintenance is conducted in a certain period in a year (not continuously) and targeted to improve the structural condition. Rehabilitation is handling towards every damage which is not considered in the design which causes stable condition reduction to restore the stable condition reduction into the designed stable condition. Betterment is a road handling to improve road service in terms of structural and/ or geometric to reach the planned road serviceability or in another word, a betterment is conducted to improve unstable and critical road condition to restore the stable condition. A betterment is conducted to improve the strength of road structure to be able to receive increased higher axle load or the increase road capacity. The road capacity improvement program includes (1) structural improvement is a handling activity which enables improvement of the unstable or critical road links to reach stable service according to the determined design life, and (2) capacity improvement is a road handling activity to widen the pavement both with or without additional lanes.

According to Volovski et al [2] in 2017, annual maintenance expenditures estimates are very important for:

- Analyzing trade-offs between preventive and corrective maintenance and between rehabilitation and maintenance.

- Long-term planning and budgeting for maintenance.

- Measuring the long-term cost of damage due to extra-legal users (e.g., overweight vehicles).

- Life-cycle costing; life-cycle evaluation of alternative designs, materials, and repair policies.

- Analyzing the cost-effectiveness of treatments that vary by application attributes (location, contractor, timing, etc.).

- Carrying out the commensurate allocation of highway expenditure among users (vehicle classes).

- Policy-making for cost-related factors.

Although the cost for maintenance is substantially less than construction and/ or rehabilitation, as this is a continuous activity, it should be under consideration.

Arianto et al [3] in 2018 stated that the International Roughness Index (IRI) together with Surface Distress Index (SDI) can be used to assess the national road in Sumenep Regency. To become more practical, the IRI was measured using a smart-phone based application called Roadroid through smart-phone vibration sensors. Meanwhile, SDI uses the total crack area parameters, average crack width, total number of potholes and the average depth of rutting.

Shah et al [4] in 2013 in India developed Overall Pavement Condition Index (OPCI) for the urban road network. This index was calculated using measurements of longitudinal and transverse cracking, alligator cracking, potholes, rut depth, patching, ravelling, roughness, structural 
deflection and skid resistance for all the selected urban road sections.

Tsu \& Tsai [5] in 2012 found that transportation bodies have suffered demanding budget declines lately. Therefore, many road preservations and rehabilitation activities have been seriously delayed. The budget consequences of delaying pavement rehabilitation required to be quantified so budget requirements can be decided scientifically. Although research based on hypothetical data have been carried out to assess the effect of delaying treatments, there is no research using actual data to quantify the budget consequences of delaying pavement rehabilitation. This research is encouraged by the requirement to overcome this condition. A method that calculates the budget consequences of delaying rehabilitation using real empirical data is proposed. The proposed method uses life-cycle-cost analysis (LCCA) and a composite performance indicator, pavement condition rating (PCR), to decide the time for improvement.

The current research is intended to evaluate which part of the road requires higher priority to be handled compared to other parts using analytical hierarchy process (AHP). AHP is a structured multi-criteria decision making procedure developed by Saaty [6].

\section{METHOD}

According to the General Specification of the Ministry of Public Works and Public Housing [7] in 2018 there were six aspects to be considered in the national road maintenance, i.e. (A) Pavement, (B) Shoulder, (C) Drainage, (D) Road Furniture, (E) Additional Building, and (F) Plantation Control.

Pavement maintenance (A) consists of road pavement work to maintain the evenness of traffic lane surface including patching the potholes (A1) filling the structural and small cracks (A2) and joint sealant (A5), spot levelling due to depression (A3), faulting (A4) in rigid pavement, overlay unevenness (A6) in flexible pavement, corrugated amplitude (A7) and rut depth (A8).

Shoulder maintenance (B) consists of the works to repair the existing road shoulder surface in order to maintain the inclination of the cross-section through patching the potholes (B1), maintain the shoulder elevation by cleaning the plantation (B2), spot levelling due to depression (B3), joint sealant (B4) and the cleanness of shoulder surface (B5).

Drainage maintenance $(\mathrm{C})$ is conducted to keep drainage system of the existing road functioning well, including side ditch, transversal ditch, outlet/inlet, manhole, all types of ditches (C1) and slope of embankment and excavation (C2).

Road furniture maintenance (D) is conducted to maintain all of the road sign (D1) both as a warning and guidance in the existing road to be able to function well (readable due to appropriate reflectivity. This work consists of cleaning and repairing road signs, delineators, distance stakes, guardrails (D3) repainting the road sign, repainting the unclear curbs/ median (D2) and road marking, plantation control and cutting down the trees covering sight distance or causing other hazards such as the roots of the trees.

The maintenance of the additional building (E) is conducted to avoid larger damage on the existing additional buildings such as approach slab of a bridge (E1), retaining wall (E2), curbs, islands, pedestrian crossing facilities, expansion joint between bridge and road, and bridge parapet/ fence.

The plantation control (F) consists of cleaning the location along with the road link so that surrounding the ends of the culverts, side ditches, the road signs, guardrails, delineators, light poles, shoulders, the lower structure of the bridges and slab of bridges. In the area of embankments and excavations including cutting the grasses, bushes and small trees with a height of small trees of $10 \mathrm{~cm}$ or over and/ or repairing within and alongside the road or to improve sight distance in the curve during the slope stabilization work. Therefore, the road is free from surrounding plantation (F1) and height of plantation (F2).

Questionnaires contain all combinations of pairs between $\mathrm{A}$ to $\mathrm{F}$, between $\mathrm{A} 1$ to $\mathrm{A} 6$, between $\mathrm{B} 1$ to $\mathrm{B} 3$, between $\mathrm{C} 1$ to $\mathrm{C} 2$, between $\mathrm{D} 1$ to $\mathrm{D} 3$, between $\mathrm{E} 1$ to $\mathrm{E} 4$ and between $\mathrm{F} 1$ and F2. 30 respondents were asked to fill out the questionnaires to choose which one of the pair members (element) was more important to be handled in road maintenance program than the other by circling a number between 1 to 9 :

- 1 means both elements have the same importance.

- 3 means one element is slightly more important than the other element.

- 5 means one element is more important than the other element.

- 7 means one element is strongly more important than the other element.

- 9 means one element is more important than the other element.

- 2, 4, 6, 8 means importance between nearest odd numbers.

The 30 respondents consist of:

1) Four Chiefs of National Road Office in Banten Province.

2) Seven Chiefs of National Road Office in Banten Province on Each Long Segment.

3) Seven Consultants for Banten Province who supervised different long segments.

4) Seven Contractors for Banten Province who supervised different long segments.

5) Five officers from districts and villages passed by the long segments.

We use the Expert Choice software to conduct the AHP. The consistency ratio (CR) for all analysis should be less than $10 \%$. 


\section{RESULT}

TABLE I shows the analysis result of the comparison between pairs of aspects in road maintenance. $\mathrm{CR}=0.02$. It can be seen that the respondents considered that the drainage was the important aspects of national road maintenance. This is quite understandable as failure to maintain the drainage may cause damage to overall road structure especially the road pavement. As predicted road furniture got less weight as their existence are not directly related to the condition of other elements of the road.

TABLE I. WEIGHT OF EACH ASPECT

\begin{tabular}{|l|l|}
\hline \multicolumn{1}{|c|}{ Aspect } & \multicolumn{1}{c|}{ Weight } \\
\hline Drainage & 0.251 \\
\hline Pavement & 0.228 \\
\hline Shoulder & 0.152 \\
\hline Additional Building & 0.132 \\
\hline Plantation Control & 0.120 \\
\hline Road Furniture & 0.117 \\
\hline
\end{tabular}

TABLE II shows the analysis result of the comparison between pairs of elements in road pavement maintenance. $\mathrm{CR}=0.02$.

TABLE II.

WEIGHT OF EACH ASPECT

\begin{tabular}{|l|l|}
\hline \multicolumn{1}{|c|}{ Elements } & \multicolumn{1}{c|}{ Weight } \\
\hline Pothole & 0.240 \\
\hline Depression & 0.170 \\
\hline Faulting & 0.122 \\
\hline Rut depth & 0.116 \\
\hline Unevenness & 0.099 \\
\hline Crack & 0.093 \\
\hline Corrugated amplitude & 0.081 \\
\hline Joint sealant & 0.078 \\
\hline
\end{tabular}

It can be seen that pothole was considered as the most important elements in road pavement maintenance with a weight of 0.240 . This was also understandable as untreated pothole will cause wider pothole in short periods.

TABLE III shows the analysis result of the comparison between pairs of elements in road shoulder maintenance. $\mathrm{CR}=0.02$. It can be seen that faulting was considered as the most important elements in road shoulder maintenance with a weight of 0.296 .

TABLE III. WEIGHT OF EACH ELEMENT IN ROAD SHOULDER MAINTENANCE

\begin{tabular}{|l|l|}
\hline \multicolumn{1}{|c|}{ Elements } & \multicolumn{1}{c|}{ Weight } \\
\hline Depression & 0.296 \\
\hline Elevation & 0.225 \\
\hline Joint sealant & 0.182 \\
\hline Cleanness of shoulder surface & 0.152 \\
\hline Pothole in shoulder & 0.145 \\
\hline
\end{tabular}

TABLE IV shows the analysis result of the comparison between pairs of elements in road drainage maintenance. $\mathrm{CR}<0.01$. It can be seen that all elements of drainage were considered as the most important elements in road pavement maintenance with a weight of 0.620 .
TABLE IV. WEIGHT OF EACH ELEMENT IN ROAD DRAINAGE MAINTENANCE

\begin{tabular}{|l|l|}
\hline \multicolumn{1}{|c|}{ Elements } & Weight \\
\hline All elements of drainage & 0.620 \\
\hline Slope of embankment and excavation & 0.380 \\
\hline
\end{tabular}

TABLE V shows the analysis result of the comparison between pairs of elements in the road furniture maintenance. $\mathrm{CR}=0.03$. It can be seen that guardrails were considered as the most important elements in road drainage maintenance with a weight of 0.364 as they were very important to maintain safe driving along the road. However, the weight between the 3 elements only slightly differed. This implies that the importance of them was almost the same.

TABLE V. WEIGHT OF EACH ELEMENT IN ROAD FURNITURE MAINTENANCE

\begin{tabular}{|l|l|}
\hline \multicolumn{1}{|c|}{ Elements } & \multicolumn{1}{c|}{ Weight } \\
\hline Guardrails & 0.364 \\
\hline Warning and direction road sign & 0.324 \\
\hline Medians or curbs & 0.312 \\
\hline
\end{tabular}

TABLE VI shows the analysis result of the comparison between pairs of elements in the additional building maintenance. $\mathrm{CR}<0.01$. It can be seen that the retaining walls were considered as the most important elements in additional building maintenance with a weight of 0.545 as their stability was very important to maintain the road accessibility. However, the weight between the 2 elements only slightly differed. This implies that the importance of them was almost the same.

TABLE VI. WEIGHT OF EACH ELEMENT IN THE AdDitionaL BUILDING MAINTENANCE

\begin{tabular}{|l|l|}
\hline \multicolumn{1}{|c|}{ Elements } & Weight \\
\hline Retaining walls & 0.545 \\
\hline Approach slab of a bridge & 0.455 \\
\hline
\end{tabular}

TABLE VII shows the analysis result of the comparison between pairs of elements in the plantation control. $\mathrm{CR}<0.01$. It can be seen that free from surrounding plantation was considered as the most important elements in the plantation control with a weight of 0.546 as their stability was very important to maintain the road accessibility and visibility. However, the weight between the 2 elements was only slightly differing. This implies that the importance of them was almost the same.

TABLE VII. WEIGHT OF EACH ElEMENT IN THE Plantation CONTROL

\begin{tabular}{|l|l|}
\hline \multicolumn{1}{|c|}{ Elements } & Weight \\
\hline Free from surrounding plantation & 0.546 \\
\hline Plantation height & 0.454 \\
\hline
\end{tabular}

\section{CONCLUSIONS AND RECOMMENDATIONS}

From the analysis in the paper, it can be concluded that for the case of maintenance of the national road in Banten Province:

1) Drainage was the most important aspect compared to the other five aspects. 
2) Within each aspect, the most important element was as follows:

a) Pavement: pothole

b) Shoulder: depression

c) Drainage: all elements of drainage

d) Road furniture: guardrail

e) Additional building: retaining wall

f) Plantation control: free from surrounding plantation

\section{REFERENCES}

[1] Government of the Republic of Indonesia, Law No.22 On Traffic and Road Transport, 2009.

[2] M. Volovski, J. Murillo-Hoyos, T.U. Saeed, S. Labi, J. Transp. Eng., Part A: Systems, vol. 143, 5, 2017.

[3] T. Arianto, M. Suprapto, and Syafi'I, IOP Conf. Series: Mat. Sci. \& Eng. vol. 333, 2018.

[4] Y.U. Shah, S.S. Jain, D. Tiwari, and M.K. Jain, Proc. - Soc. \& Beh. Sci., vol. 104, 2013.

[5] Y. Xu, \& Y. Tsai, Y. J. Transp. Eng. vol. 138. 2012.

[6] T.L. Saaty \& L.G. Vargas, "Methods, Concepts, and Applications of the Analytic Hierarchy Process, 2nd ed." Springer Science \& Business Media, 2012.

[7] Government of the Republic of Indonesia, General Specification of the Ministry of Public Works and Public Housing, 2018. 